\title{
Heterotrimetallic Cyanide-Bridged 3d-4d-5d Frameworks Based on a Photomagnetic Secondary Building Unit
}

\author{
Michał Magott,* Marcin Sarewicz, Szymon Buda, and Dawid Pinkowicz* \\ Cite This: Inorg. Chem. 2020, 59, 8925-8934 \\ Read Online
}

ABSTRACT: The rational design of coordination frameworks combining more than two different metal ions using a self-assembly approach is challenging because it rarely offers sufficient control over the building blocks at the actual self-assembly stage. In this work, we present a successful two-step strategy toward heterotrimetallic coordination frameworks by employing a new bimetallic $\left[(\mathrm{NC})_{7} \mathrm{Mo}^{\mathrm{IV}}-\mathrm{CN}-\mathrm{Pt}^{\mathrm{IV}}\left(\mathrm{NH}_{3}\right)_{4}-\mathrm{NC}-\mathrm{Mo}^{\mathrm{IV}}(\mathrm{CN})_{7}\right]^{4-}$ secondary building unit (SBU). This anionic moiety has been isolated and characterized as a simple salt with an organic dppipH ${ }_{2}{ }^{2+}$ cation $\left(\mathrm{dppipH}_{2}\right)_{2}\left[(\mathrm{NC})_{7} \mathrm{Mo}^{\mathrm{IV}}-\mathrm{CN}-\mathrm{Pt}^{\mathrm{IV}}\left(\mathrm{NH}_{3}\right)_{4}-\mathrm{NC}-\mathrm{Mo}^{\mathrm{IV}}(\mathrm{CN})_{7}\right] \cdot 15 \mathrm{H}_{2} \mathrm{O}$ (1) (dppip $=1,4-\operatorname{di}(4$-pyridinyl)piperazine). The salt presents a second-order phase transition related to cation conformational change

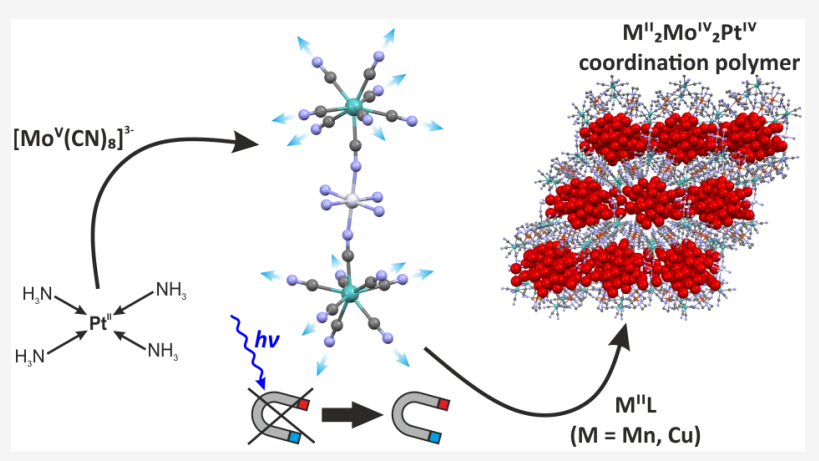
around $250 \mathrm{~K}$ and a photomagnetic effect after irradiation with 450 $\mathrm{nm}$ light at $10 \mathrm{~K}$. When combined with aqueous solutions of $\mathrm{Mn}^{\mathrm{II}}$ or $\mathrm{Cu}^{\mathrm{II}}$ complexes, it forms either a one-dimensional chain $\left[\mathrm{Mn}^{\mathrm{II}}(\right.$ dpop $\left.)\right]\left[\mathrm{Mn}^{\mathrm{II}}(\mathrm{dpop})\left(\mathrm{H}_{2} \mathrm{O}\right)\right]\left[(\mathrm{NC})_{7} \mathrm{Mo}^{\mathrm{IV}}-\mathrm{CN}_{-} \mathrm{Pt}^{\mathrm{IV}}\left(\mathrm{NH}_{3}\right)_{4}-\mathrm{NC}-\mathrm{Mo}^{\mathrm{IV}}(\mathrm{CN})_{7}\right] \cdot 36 \mathrm{H}_{2} \mathrm{O}$ (2) (dpop = 2,13-dimethyl-3,6,9,12,18pentaazabicyclo-[12.3.1] octadeca-1(18),2,12,14,16-pentaene) or a photomagnetic two-dimensional honeycomb network $\left[\mathrm{Cu}^{\mathrm{II}}(\mathrm{cyclam})\right]_{2}\left[(\mathrm{NC})_{7} \mathrm{Mo}^{\mathrm{IV}}-\mathrm{CN}-\mathrm{Pt}^{\mathrm{IV}}\left(\mathrm{NH}_{3}\right)_{4}-\mathrm{NC}-\mathrm{Mo}^{\mathrm{IV}}(\mathrm{CN})_{7}\right] \cdot 40.89 \mathrm{H}_{2} \mathrm{O}$ (3) (cyclam = 1,4,8,11-tetraazacyclotetradecane), both characterized by very large cavities in their structure filled with solvent molecules. Both 2 and 3 incorporate three different transitionmetal ions and constitute a new family of $3 \mathrm{~d}-4 \mathrm{~d}-5 \mathrm{~d}$ coordination frameworks. Moreover, compound 3 inherits the photomagnetic properties of the MoPtMo SBU.

\section{INTRODUCTION}

Porous coordination polymers attract nonvanishing interest due to numerous functionalities arising from their flexible porous structure $^{1,2}$ such as gas storage, luminescent sensing, or nonlinear optical properties. ${ }^{3-6}$ However, the combination of magnetism and porosity remains a challenge because long spacer ligands required to promote large pores in the structure lead to very weak magnetic interactions ${ }^{7-9}$ while short bridging ligands known for providing good electronic contact between metal ions in magnetic networks (i.e., $\mathrm{F}^{-10-12} \mathrm{C}_{2} \mathrm{O}_{4}{ }^{2-13}$ or $\mathrm{CN}^{-14,15}$ ) usually facilitate the formation of dense structures, preventing large molecules from entering pores and limiting sorption to small solvent molecules ${ }^{1-19}$ and oxygen. ${ }^{20}$ Magnetization switching by the adsorption of relatively large molecules (i.e., benzene, naphthalene, or anthracene) was presented for Hoffman-type frameworks $\left[\mathrm{Fe}^{\mathrm{II}} \mathrm{L}\right]\left[\mathrm{M}^{\mathrm{II}}(\mathrm{CN})_{4}\right](\mathrm{L}$ $=$ pyrazine, 1,2-di (4-pyridyl)ethylene; $\left.\mathrm{M}^{\mathrm{II}}=\mathrm{Ni}^{\mathrm{II}}, \mathrm{Pd}^{\mathrm{II}}, \mathrm{Pt}^{\mathrm{II}}\right)^{21,22}$ demonstrating solvent-dependent SCO switching but not longrange magnetic ordering. In order to counter these drawbacks, it has been proposed to combine the magnetic functionality and the elongated character of a spacer-type ligand in a single entity-a secondary building unit (SBU) ${ }^{8,23-26}$ In principle, these SBUs can be composed of magnetically coupled centers that form an elongated bridging unit, enabling the formation of a porous framework while maintaining strong magnetic superexchange interactions. Nonetheless, reports regarding rodlike metallo-ligands or SBUs are scarce, and as far as we know, a photomagnetic building block for the construction of porous networks has not yet been presented.

In this work, we have studied the crystal structure and photomagnetic activity of a new complex salt $\left(\text { dppipH }_{2}\right)_{2}\left[(\mathrm{NC})_{7} \mathrm{Mo}^{\mathrm{IV}}-\mathrm{CN}-\mathrm{Pt}^{\mathrm{IV}}\left(\mathrm{NH}_{3}\right)_{4}-\mathrm{NC}-\mathrm{Mo}^{\mathrm{IV}}(\mathrm{CN})_{7}\right]$. $15 \mathrm{H}_{2} \mathrm{O}(1)$ comprising anionic rodlike $\left[(\mathrm{NC})_{7} \mathrm{Mo}^{\mathrm{IV}}-\mathrm{CN}\right.$ $\left.\mathrm{Pt}^{\mathrm{IV}}\left(\mathrm{NH}_{3}\right)_{4}-\mathrm{NC}-\mathrm{Mo}^{\mathrm{IV}}(\mathrm{CN})_{7}\right]^{4-}$ (MoPtMo) SBUs similar to those reported by Podgajny et al. ${ }^{27}$ This work was inspired by $\left[\mathrm{Fe}(\mathrm{CN})_{6}\right]$-based compound $\left[\mathrm{Pt}^{\mathrm{II}}\left(\mathrm{NH}_{3}\right)_{4}\right]_{2}\left[(\mathrm{NC})_{5} \mathrm{Fe}^{\mathrm{II}}-\mathrm{CN}\right.$ $\left.\mathrm{Pt}^{\mathrm{IV}}\left(\mathrm{NH}_{3}\right)_{4}-\mathrm{NC}-\mathrm{Fe}^{\mathrm{II}}(\mathrm{CN})_{5}\right] \cdot 9 \mathrm{H}_{2} \mathrm{O}(\mathrm{FePtFe})$ reported by Bocarsly et al. in $1990^{28}$ obtained as a product of a redox reaction between $\left[\mathrm{Pt}^{\mathrm{II}}\left(\mathrm{NH}_{3}\right)_{4}\right]\left(\mathrm{NO}_{3}\right)_{2}$ and $\mathrm{K}_{3}\left[\mathrm{Fe}^{\mathrm{III}}(\mathrm{CN})_{6}\right]$. Visible-light irradiation of $\mathrm{FePtFe}$ solution within its MMCT

Received: March 11, 2020

Published: June 8, 2020 
band regenerates initial substrates $\mathrm{Pt}^{\mathrm{II}}$ and $\mathrm{Fe}^{\mathrm{III}}$, which was demonstrated by the color change from intense red to yellow. ${ }^{29}$ Similar behavior was observed by means of IR spectroscopy for the solid obtained in the reaction of $\left[\mathrm{Pt}^{\mathrm{II}}\left(\mathrm{NH}_{3}\right)_{4}\right]_{2}\left[(\mathrm{NC})_{5} \mathrm{Fe}^{\mathrm{II}}-\mathrm{CN}-\mathrm{Pt}^{\mathrm{IV}}\left(\mathrm{NH}_{3}\right)_{4}-\mathrm{NC}-\mathrm{Fe}^{\mathrm{II}}(\mathrm{CN})_{5}\right]$. $9 \mathrm{H}_{2} \mathrm{O}$ with $\mathrm{NiCl}_{2}$ in water, which after $488 \mathrm{~nm}$ light irradiation gives a powder $\mathrm{X}$-ray diffraction pattern resembling that of nickel ferricyanide. ${ }^{30}$ The generation of paramagnetic components after light irradiation is promising for the construction of photomagnetic compounds, a group of materials in which magnetization change can be triggered by light. ${ }^{14}$ At the same time, the linear nature of such an anion could facilitate the formation of extended networks. (See Figure 1 for a comparison with typical organic linkers used for

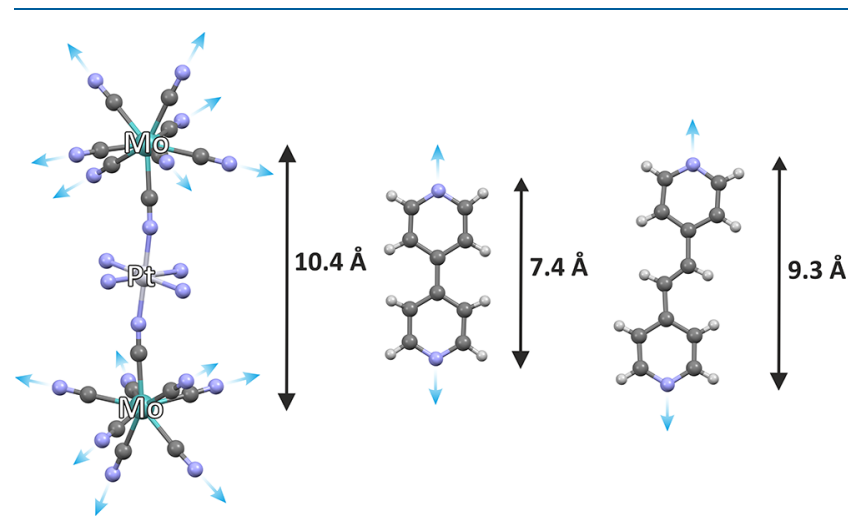

Figure 1. Shape and size comparison of $\left[(\mathrm{NC})_{7} \mathrm{Mo}^{\mathrm{IV}}-\mathrm{CN}\right.$ $\left.\mathrm{Pt}^{\mathrm{IN}}\left(\mathrm{NH}_{3}\right)_{4}-\mathrm{NC}-\mathrm{Mo}^{\mathrm{IV}}(\mathrm{CN})_{7}\right]^{4-} \mathrm{SBU}$ with $4,4^{\prime}$-bipyridine and 1,2 di(4-pyridyl)ethylene. Blue arrows demonstrate the bridging possibilities. $\mathrm{H}$ atoms of the amine ligands are omitted for clarity.

MOF synthesis, such as 4,4'-bipyridine ${ }^{31,32}$ and 1,2-di(4pyridyl)ethylene). ${ }^{33,34}$ However, due to the difficulty in crystallizing coordination polymers containing hexacyanometallates, which often form weakly crystalline Prussian blue analogues, octacyanometallates are more convenient from a synthesis viewpoint. Indeed, octacyanomolybdate-based anion $\left[(\mathrm{NC})_{7} \mathrm{Mo}^{\mathrm{IV}}-\mathrm{CN}-\mathrm{Pt}^{\mathrm{IV}}\left(\mathrm{NH}_{3}\right)_{4}-\mathrm{NC}-\mathrm{Mo}^{\mathrm{IV}}(\mathrm{CN})_{7}\right]^{4-}$ was reported to exist in aqueous solution in 2001, but the crystal structure was determined only for $\mathrm{Cs}_{2}\left[\mathrm{Pt}^{\mathrm{IV}}(\mathrm{en})_{2} \mathrm{Cl}_{2}\right]$ $\left[(\mathrm{CN})_{7} \mathrm{Mo}^{\mathrm{IV}}-\mathrm{CN}-\mathrm{Pt}^{\mathrm{IV}}(\mathrm{en})_{2}-\mathrm{NC}-\mathrm{Mo}^{\mathrm{IV}}(\mathrm{CN})_{7}\right] \cdot 10 \mathrm{H}_{2} \mathrm{O} \quad(\mathrm{en}=$ ethylenediamine $){ }^{27}$ Although the substitution of ammonia with ethylenediamine should not strongly affect the chargetransfer properties of a molecule, an outer-sphere platinum(IV) complex may interact with the anion and complicate the analysis of light-driven changes in this compound. Therefore, we decided to reinvestigate the synthesis and prepare a salt of $\left[(\mathrm{NC})_{7} \mathrm{Mo}^{\mathrm{IV}}-\mathrm{CN}-\mathrm{Pt}^{\mathrm{IV}}\left(\mathrm{NH}_{3}\right)_{4}-\mathrm{NC}-\mathrm{Mo}^{\mathrm{IV}}(\mathrm{CN})_{7}\right]^{4-}$ with a redox-innocent organic cation to facilitate its photomagnetic studies. Afterward, two heterotrimetallic ${ }^{35}$ coordination networks have been prepared with the use of MoPtMo SBU: $\left[\mathrm{Mn}^{\mathrm{II}}(\mathrm{dpop})\right]\left[\mathrm{Mn}^{\mathrm{II}}(\mathrm{dpop})\left(\mathrm{H}_{2} \mathrm{O}\right)\right]\left[(\mathrm{NC})_{7} \mathrm{Mo}^{\mathrm{IV}}-\mathrm{CN}\right.$ $\left.\mathrm{Pt}^{\mathrm{IV}}\left(\mathrm{NH}_{3}\right)_{4}-\mathrm{NC}-\mathrm{Mo}^{\mathrm{IV}}(\mathrm{CN})_{7}\right] \cdot 36 \mathrm{H}_{2} \mathrm{O}$ (2) (dpop = 2,13-dimethyl-3,6,9,12,18-pentaazabicyclo-[12.3.1] octadeca$1(18), 2,12,14,16$-pentaene $)$ and $\left[\mathrm{Cu}^{\mathrm{II}}(\text { cyclam })\right]_{2}\left[(\mathrm{NC})_{7} \mathrm{Mo}^{\mathrm{IV}}\right.$ $\left.\mathrm{CN}-\mathrm{Pt}^{\mathrm{IV}}\left(\mathrm{NH}_{3}\right)_{4}-\mathrm{NC}-\mathrm{Mo}^{\mathrm{IV}}(\mathrm{CN})_{7}\right] \cdot 40.89 \mathrm{H}_{2} \mathrm{O}$ (3) (cyclam = 1,4,8,11-tetraazacyclotetradecane), both of which contain large water-filled cavities in their structures.

\section{SYNTHESIS AND STRUCTURE OF 1}

The water solution of the $\left[(\mathrm{NC})_{7} \mathrm{Mo}^{\mathrm{IV}}-\mathrm{CN}-\mathrm{Pt}^{\mathrm{IV}}\left(\mathrm{NH}_{3}\right)_{4}-\mathrm{NC}\right.$ $\left.\mathrm{Mo}^{\mathrm{IV}}(\mathrm{CN})_{7}\right]^{4-}$ anion is obtained in a redox reaction occurring immediately after mixing a sodium salt of octacyanomolybdate(V) with $\left[\mathrm{Pt}^{\mathrm{II}}\left(\mathrm{NH}_{3}\right)_{4}\right]\left(\mathrm{NO}_{3}\right)_{2}$ in water for $n_{\mathrm{Mo}} / n_{\mathrm{Pt}}=2: 1$. This immediately leads to the formation of a dark-red solution (details in the SI). In an attempt to obtain a binary ionic salt of this bimetallic anion, we performed test reactions with a variety of organic cations. No solid product was obtained after the addition of saturated solutions of tetrabutylammonium chloride (TBACl) or tetraphenylphosphonium bromide $\left(\mathrm{Ph}_{4} \mathrm{PBr}\right)$ salts. Reaction with bis(triphenylphosphoranylidene)ammonium chloride ( $\mathrm{PPNCl}$ ) affords a pink precipitate, which in time transforms into an amorphous solid. In order to facilitate the formation of a crystalline product, we decided to use highly charged cations formed by the protonation of organic bases such as 4,4'-bipyridine and 2,2'-bipyridine with a small excess of nitric acid. However, even for saturated solutions of the corresponding salts no solid was obtained. Upon addition of a protonated 1,4,8,11-tetraazacyclodecane, we have observed the formation of red columnar crystals. They were found by single-crystal $\mathrm{X}$-ray diffraction to be $\left(\mathrm{cyclamH}_{4}\right)\left[\mathrm{Mo}^{\mathrm{IV}}(\mathrm{CN})_{8}\right] \cdot 1.5 \mathrm{H}_{2} \mathrm{O}$, despite the unusual color and shape of crystals, differing from yellow needles previously observed for this compound. ${ }^{36}$ Only the use of a protonated 1,4-di(4-pyridinyl)piperazine similar in size and shape to $\left[(\mathrm{NC})_{7} \mathrm{Mo}^{\mathrm{IV}}-\mathrm{CN}-\mathrm{Pt}^{\mathrm{IV}}\left(\mathrm{NH}_{3}\right)_{4}-\mathrm{NC}-\mathrm{Mo}^{\mathrm{IV}}(\mathrm{CN})_{7}\right]^{4-}$ resulted in the formation of crystalline compound 1 . (See the synthesis details in the SI for more details.)

Single-crystal X-ray diffraction studies at $120 \mathrm{~K}$ revealed that compound 1 crystallizes in a triclinic $P \overline{1}$ space group, where both cations and anions form chains along the crystallographic $a$ axis (Figure 2a). The asymmetric unit consists of two a)

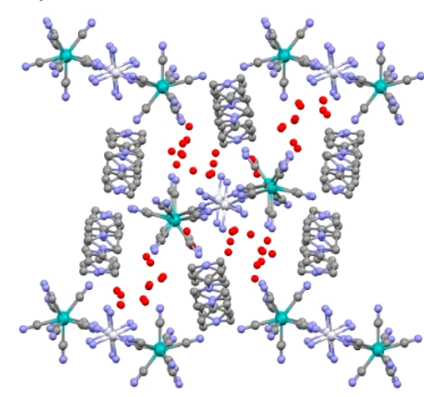

b)

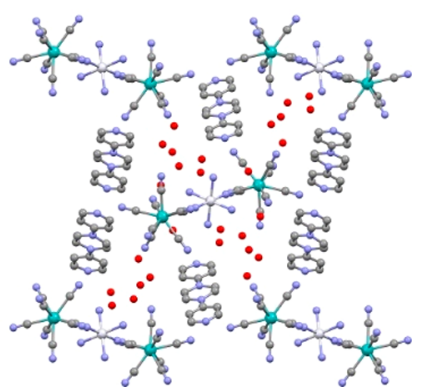

Figure 2. Crystal cell of 1 visible along the $a$ axis at (a) 120 and (b) $255 \mathrm{~K}$. White, Pt; green, Mo; red, O; blue, N; gray, C. Hydrogen atoms were omitted for clarity.

$\left[(\mathrm{NC})_{7} \mathrm{Mo}^{\mathrm{IV}}-\mathrm{CN}-\mathrm{Pt}^{\mathrm{IV}}\left(\mathrm{NH}_{3}\right)_{4}-\mathrm{NC}-\mathrm{Mo}^{\mathrm{IV}}(\mathrm{CN})_{7}\right]^{4-}$ anions and four 1,4-di(4-pyridinyl)piperazine cations accompanied by 30 water molecules. The formation of cyanide bridges between platinum(II) and octacyanomolybdate is confirmed by a short average $\mathrm{Pt}-\mathrm{N}_{\text {cyanide }}$ bond length of 1.962(4) $\AA$, similar to $1.972(7) \AA$ reported for $\mathrm{Pt}-\mathrm{N}_{\text {cyanide }}$ bonds in $\left[(\mathrm{NC})_{7} \mathrm{Mo}^{\mathrm{IV}}\right.$ $\left.\mathrm{CN}-\mathrm{Pt}^{\mathrm{IV}}(\mathrm{en})_{2}-\mathrm{NC}-\mathrm{Mo}^{\mathrm{IV}}(\mathrm{CN})_{7}\right]^{4-27}$ and $1.971(11) \AA$ in $\left[(\mathrm{NC})_{5} \mathrm{Fe}^{\mathrm{II}}-\mathrm{CN}-\mathrm{Pt}^{\mathrm{IV}}\left(\mathrm{NH}_{3}\right)_{4}-\mathrm{NC}-\mathrm{Fe}^{\mathrm{II}}(\mathrm{CN})_{5}\right]^{4-28}$ The two anionic units differ slightly with respect to $\mathrm{Pt}-\mathrm{N}-\mathrm{C}$ angles, with 175.4(6) and 167.8(6) ${ }^{\circ}$ for Pt1 and 170.3(7) and $165.4(7)^{\circ}$ for Pt2. Small differences are also observed for octacyanomolybdate coordination geometry, which in all cases is intermediate between square antiprism and dodecahedron, 
closer to the former in the cases of Mo1, Mo3, and Mo4 but approaching the latter for Mo2 (Table S1 in the SI for detailed $\mathrm{SHAPE}^{37}$ analysis). Similar to anions, all 1,4-di(4-pyridinyl)piperazine cations in the structure of 1 differ only slightly. The twist angle $\varphi$ between pyridinium rings on average equals $42(2)^{\circ}$ as presented in Figure 3a. All piperazinium rings adopt

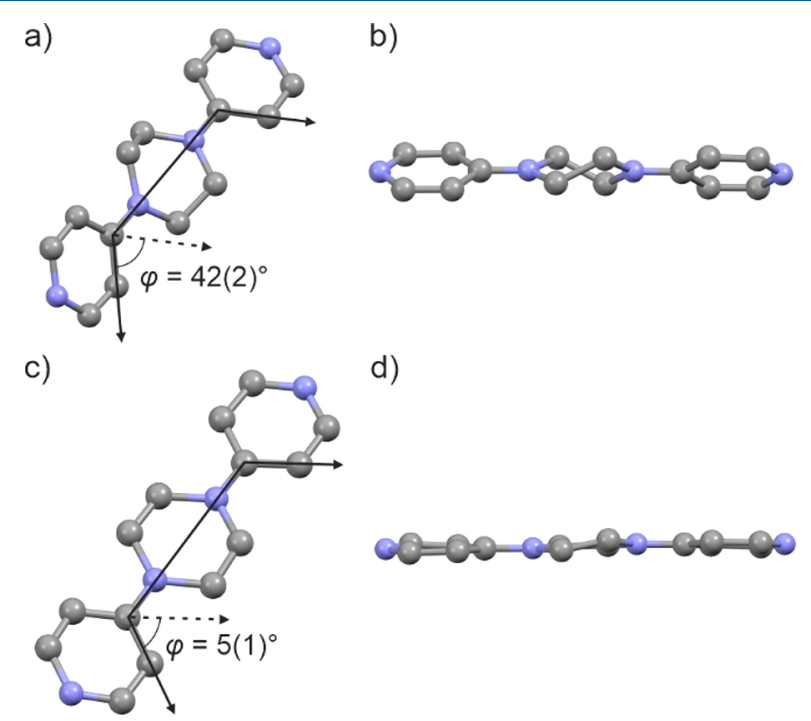

Figure 3. 1,4- $\mathrm{Di}(4-$ pyridinyl)piperazine cation as visible in the structure of 1 at ( $a$ and b) $120 \mathrm{~K}$ and (c and d) $255 \mathrm{~K}$. Blue, N; gray, C. Hydrogen atoms were omitted for clarity.

an unusual twist-boat conformation resembling that observed in twistane (Figure $3 \mathrm{~b}$ ), ${ }^{41}$ which was previously observed for similar cations. ${ }^{42,43}$ The whole structure is stabilized by hydrogen bonds between octacyanomolybdate cyanides and protonated pyridyl rings as well as numerous hydrogen bonds formed by crystallization water molecules with cyanides and ammonia ligands coordinated to platinum(IV).

The experimental powder X-ray diffraction pattern for 1 obtained at room temperature and the PXRD pattern simulated from its crystal structure at $120 \mathrm{~K}$ are quite similar; however, some differences can be easily spotted (Figure S1). An increased number of diffraction peaks predicted for the latter cannot be explained only by the thermal expansion of the crystal lattice and random overlap of reflections. As this may be a symptom of a phase transition occurring between the temperature of a single-crystal measurement $(120 \mathrm{~K})$ and the PXRD experiment (room temperature), we decided to perform a differential scanning calorimetry (DSC) measurement. Indeed a small but broad feature at around $250 \mathrm{~K}$ is observed (Figure S3), which may suggest that $\mathbf{1}$ undergoes a secondorder phase transition. Therefore, an additional single-crystal diffraction experiment was performed at $255 \mathrm{~K}$, above the transition temperature but much below room temperature, to prevent desolvation and crystal fracture. The high-temperature structure was solved and refined in the monoclinic $P 2_{1} / n$ space group and differs significantly from the low-temperature phase (Figure 2b). Moreover, the PXRD pattern simulated from the high-temperature structural model perfectly matches the experimental one collected at room temperature (Figure S2) and suggests that $\mathbf{1}$ undergoes a phase transition at around 250 $\mathrm{K}$. In the high-temperature phase, the asymmetric unit is reduced to one 1,4-di(4-pyridinyl)piperazine cation, half of an anion, and 7.5 water molecules. The anion hardly changes, as depicted by the elongation of the $\mathrm{Pt}-\mathrm{N}_{\text {cyanide }}$ bond to 1.971(10) $\AA$ and the $\mathrm{Pt}-\mathrm{N}-\mathrm{C}$ angle equal to $165.8(10)^{\circ}$. On the other hand, there is a visible difference regarding the cation, as pyridyl rings in the high-temperature phase are almost coplanar with a twist angle $\varphi$ equal to $5(1)^{\circ}$ (Figure 3c) and the piperazine ring becomes almost flat (Figure $3 \mathrm{~d}$ ). Additionally, all thermal ellipsoids of the cation are elongated perpendicular to the rings' plane. These changes may indicate that heating above the transition temperature activates the conformational freedom of the cation and a new skeletal vibration. This assumption is partially confirmed by variabletemperature infrared spectroscopy, where a change in the structure of the $1200-1270 \mathrm{~cm}^{-1}$ bands is visible during heating in the $245-275 \mathrm{~K}$ range (Figures S4-S6). Therefore, we conclude that compound $\mathbf{1}$ displays a second-order phase transition connected with the change in cation flexibility that does not visibly influence the structure of $\mathrm{Mo}-\mathrm{Pt}-\mathrm{Mo}$ anions.

\section{PHOTOMAGNETIC STUDIES OF 1}

In the structure of $\mathbf{1}$, the platinum(IV) cations are characterized by a low-spin $\mathrm{d}^{6}$ electronic configuration, and molybdenum(IV) ions have both their $\mathrm{d}^{2}$ electrons paired on the single lowest-lying orbital. This leads to a diamagnetic ground state of the Mo-Pt-Mo SBU at room temperature and below, but theoretically the paramagnetic state in $\mathbf{1}$ could be photoinduced by irradiation within at least one of its UVvis bands (Figure 4a). One could expect the photodissociation of $\left[(\mathrm{NC})_{7} \mathrm{Mo}^{\mathrm{IV}}-\mathrm{CN}-\mathrm{Pt}^{\mathrm{IV}}\left(\mathrm{NH}_{3}\right)_{4}-\mathrm{NC}-\mathrm{Mo}^{\mathrm{IV}}(\mathrm{CN})_{7}\right]^{4-}$ into two $\left[\mathrm{MoV}^{\mathrm{V}}(\mathrm{CN})_{8}\right]^{3-}(\mathrm{S}=1 / 2)$ components and $\left[\mathrm{Pt}^{\mathrm{II}}\left(\mathrm{NH}_{3}\right)_{4}\right]^{2+}$ after irradiation within the MMCT band, similar to the case of $\left[(\mathrm{NC})_{5} \mathrm{Fe}^{\mathrm{II}}-\mathrm{CN}-\mathrm{Pt}^{\mathrm{IV}}\left(\mathrm{NH}_{3}\right)_{4}-\mathrm{NC}-\mathrm{Fe}^{\mathrm{II}}(\mathrm{CN})_{5}\right]^{4-} .{ }^{29}$ However, despite the MMCT band spanning $700 \mathrm{~nm}$, no photoinduced magnetism is observed for 1 after irradiation with 690 or 640 $\mathrm{nm}$ light at $10 \mathrm{~K}$ (Figure $4 \mathrm{~b}$ ). An onset of light-induced change is observed for $585 \mathrm{~nm}$ light, when the MMCT band reaches half of its maximum intensity, with a weak photomagnetic effect visible after $530 \mathrm{~nm}$ light irradiation (Figure S7). On the other hand, there is a strong photomagnetic response after 450 $\mathrm{nm}$ light irradiation at $10 \mathrm{~K}$ (Figure 5, inset), well below $\lambda_{\max }=$ $494 \mathrm{~nm}$ for the CT band. Metastable state $1^{*}$ observed after $450 \mathrm{~nm}$ light irradiation was characterized by an $M(H)$ dependence at $T=2.0 \mathrm{~K}$ and a $\chi T(T)$ dependence in the 2$100 \mathrm{~K}$ range (Figures 5 and 6 , respectively). The $\chi T$ value of

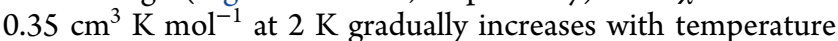
to reach a maximum of $0.80 \mathrm{~cm}^{3} \mathrm{~K} \mathrm{~mol}^{-1}$ at $40 \mathrm{~K}$, which slowly drops upon further heating. The decrease in the $\chi T$ value is likely due to the onset of thermal relaxation. The transition to the metastable state can be reversed by heating to $270 \mathrm{~K}$, but thermal relaxation to the ground state is incomplete with the remaining signal equal to $0.07 \mathrm{~cm}^{3} \mathrm{~K} \mathrm{~mol}^{-1}$. The magnetization curve shows no hysteresis and reaches $0.88 \mathrm{~N} \beta$ at $7 \mathrm{~T}$, with its shape visibly differing from the Brillouin function for a paramagnet $^{44}$ (Figure 6). Similar to the $\chi T(T)$ dependence, the remnant signal is also observed in the magnetization value at $7 \mathrm{~T}$ equal to $0.16 \mathrm{~N} \beta$ after thermal relaxation (Figure 6, blue points).

If the hypothetical photodissociation of $\left[(\mathrm{NC})_{7} \mathrm{Mo}^{\mathrm{IV}}-\mathrm{CN}\right.$ $\left.\mathrm{Pt}^{\mathrm{IV}}\left(\mathrm{NH}_{3}\right)_{4}-\mathrm{NC}-\mathrm{Mo}^{\mathrm{IV}}(\mathrm{CN})_{7}\right]^{4-}$ is complete $(100 \%$ photoconversion) and the trinuclear molecule breaks into three separate fragments consisting of a square-planar diamagnetic $\left[\mathrm{Pt}^{\mathrm{II}}\left(\mathrm{NH}_{3}\right)_{4}\right]^{2+}$ and two paramagnetic $\left[\mathrm{MoV}^{\mathrm{V}}(\mathrm{CN})_{8}\right]^{3-}$ units $(g$ $=2.0)$, the expected room-temperature $\chi T$ value would be 
a)



b)

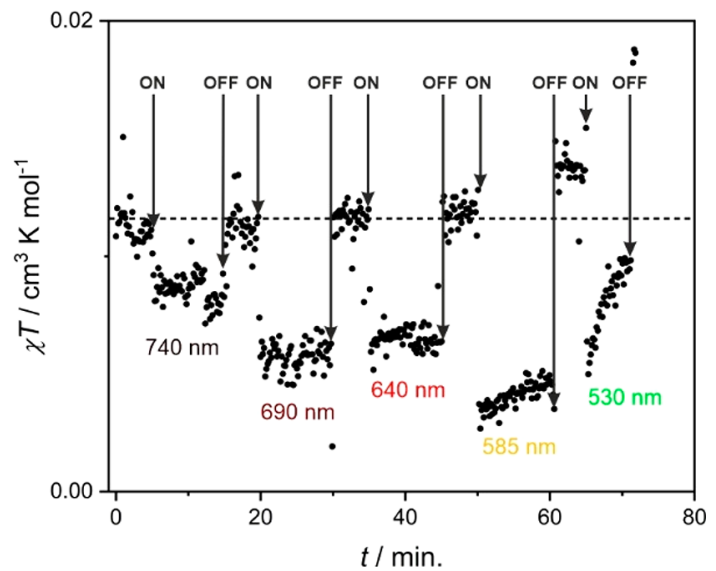

Figure 4. (a) Solid state UV-vis spectrum for 1 at room temperature. Cyan and purple dashed lines denote $\lambda=494 \mathrm{~nm}$ (MMCT band) and $\lambda=436 \mathrm{~nm}$ (approximate position of the $\mathrm{Mo}^{\mathrm{IV}}$ the $\mathrm{d}-\mathrm{d}$ transition), ${ }^{38-40}$ respectively. (b) $\chi T(t)$ for 1 during irradiation tests at $T=10 \mathrm{~K}$ and $H=0.1 \mathrm{~T}$. The dashed line represents the initial $\chi T$ level before irradiation, while labels under the experimental points indicate the irradiation light wavelength. Black arrows indicate moments when the irradiation light was turned on and off.

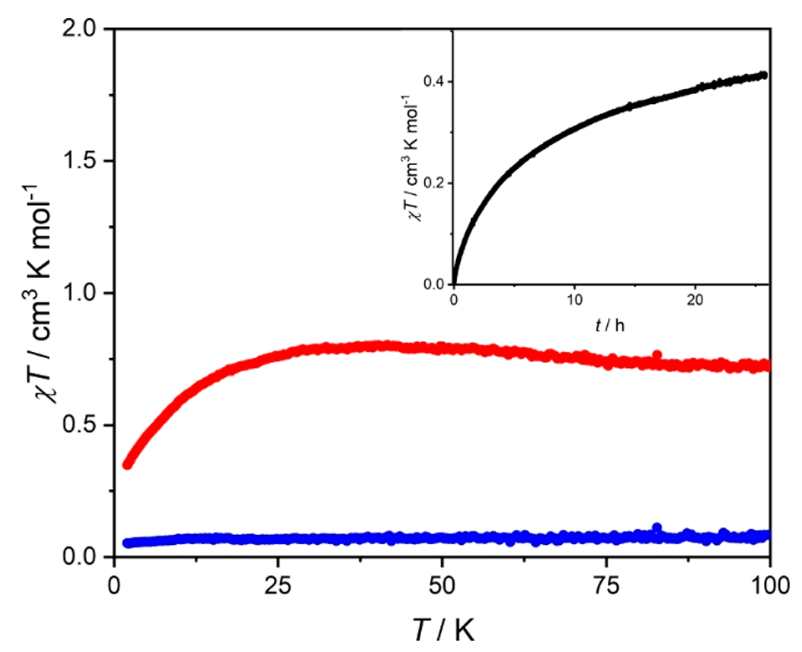

Figure 5. $\chi T(T)$ dependence for 1 after $450 \mathrm{~nm}$ light irradiation $\left(1^{*}\right.$, red points) and after thermal relaxation at $270 \mathrm{~K}$ (blue points) under $H=0.1 \mathrm{~T}$. Note that before irradiation, $\chi T=0$. (Inset) Irradiation of 1 with $\lambda=450 \mathrm{~nm}$ at $T=10 \mathrm{~K}$ and under $H=0.1 \mathrm{~T}$.



Figure 6. $M(H)$ dependence on 1 after $450 \mathrm{~nm}$ light irradiation ( $\mathbf{1}^{*}$, red points) and after thermal relaxation at $270 \mathrm{~K}$ (blue points) at $T=$ $2.0 \mathrm{~K}$. The solid line shows the Brillouin function for two noninteracting spins $(g=2.0, S=1 / 2)$, and the dashed line shows the Brillouin function for $S=1, g=2.0$ and no ZFS; a conversion efficiency of $45 \%$ was assumed for simulations.

$$
\chi T_{\mathrm{RT}}=2 \frac{\mu_{0} \mu_{\mathrm{B}}^{2}}{3 k_{\mathrm{B}}} g^{2} S(S+1)=0.75 \mathrm{~cm}^{3} \mathrm{~K} \mathrm{~mol}^{-1}
$$

and the saturation magnetization at $2.0 \mathrm{~K}$ would amount to

$$
M_{\text {sat }}=2 g S N \mu_{\mathrm{B}}=2.0 \mathrm{~N} \beta
$$

The photoinduced state undergoes thermal relaxation below room temperature, and the process seems to start at $40 \mathrm{~K}$, but the exact relaxation temperature value $T_{\text {relax }}$ cannot be determined because of the low data quality above $100 \mathrm{~K}$. However, the hypothetical $\left[\mathrm{MoV}^{\mathrm{V}}(\mathrm{CN})_{8}\right]^{3-}$ centers would be separated by $9-10 \AA$, which should lead to very weak exchange interactions not exceeding $|J|=1 \mathrm{~cm}^{-1}$. Therefore, one can expect that the $\chi T$ value at $40 \mathrm{~K}$ already approximates the $\chi T_{\mathrm{RT}}$ value for noninteracting $S=1 / 2$ centers, in which the thermal energy is much higher than the estimated exchange coupling. Saturation magnetization at $2 \mathrm{~K}$ and $\chi T$ at $40 \mathrm{~K}$ are both proportionally affected by the photoconversion efficiency, so the ratio of these two parameters is analyzed further to exclude the influence of the irradiation efficiency. The expected $M_{\text {sat }} /$ $\chi T_{40 \mathrm{~K}}$ for two $S=1 / 2$ spins would be $2.7(\mathrm{~N} \beta \mathrm{mol}) /\left(\mathrm{cm}^{3} \mathrm{~K}\right)$, while the experimental value is only $1.1(\mathrm{~N} \beta \mathrm{mol}) /\left(\mathrm{cm}^{3} \mathrm{~K}\right)$. This results from the observed magnetization value at $7 \mathrm{~T}$ being more than twice as small as expected in this scenario. Such behavior would require $S=1 / 2$ centers to be antiferromagnetically coupled, producing $m_{\mathrm{S}}=0$ and $m_{\mathrm{S}}=1$ states separated in energy by at least several wavenumbers $\left(k_{\mathrm{b}} T\right.$ $=2 \mathrm{~K}<J S^{2}$ ). However, as stated above, such strong dipoledipole interaction through space is unexpected for localized spins. On the other hand, such energy splitting is highly possible for $S \geq 1$ systems, which are commonly affected by the zero-field splitting (ZFS) effect resulting from interelectron interactions. ${ }^{45}$ In the absence of ZFS, the $S=1$ system with $g=$ 2.0 would afford $\chi T_{\mathrm{RT}}=1 \mathrm{~cm}^{3} \mathrm{~K} \mathrm{~mol}^{-1}$ and $M_{\text {sat }}=2 \mathrm{~N} \beta$ at 2.0 $\mathrm{K}$ with the $M_{\text {sat }} / \chi T_{40 \mathrm{~K}}$ ratio of $2.0(\mathrm{~N} \beta \mathrm{mol}) /\left(\mathrm{cm}^{3} \mathrm{~K}\right)$, which is much closer to the experimental value of $1.1(\mathrm{~N} \beta \mathrm{mol}) /\left(\mathrm{cm}^{3}\right.$ $\mathrm{K})$ than in the case of the $S=1 / 2$ system. Additionally, as a positive $D$ parameter may split the $S=1$ state into $m_{\mathrm{S}}=0$ and 




Figure 7. Coordination chain in 2 as seen along the $a$ axis. White, Pt; green, Mo; purple, Mn; red, O; blue, N; gray, C. Hydrogen atoms and crystallization water molecules are omitted for clarity.

1 levels, the nonmagnetic $m_{\mathrm{S}}=0$ ground state may appear, explaining the further decrease in $M_{\text {sat }}$ at $2 \mathrm{~K}$. Indeed, a large positive $D$ parameter exceeding $+20 \mathrm{~cm}^{-1}$ was recently presented for $S=1\left[\mathrm{~K}(\text { crypt-2.2.2) }]_{3}\left[\mathrm{Mo}^{\mathrm{IV}}(\mathrm{CN})_{7}\right] \cdot 3 \mathrm{CH}_{3} \mathrm{CN}\right.$, a photoproduct of $\mathrm{K}_{4}\left[\mathrm{Mo}^{\mathrm{IV}}(\mathrm{CN})_{8}\right] \cdot 2 \mathrm{H}_{2} \mathrm{O}$ irradiation. ${ }^{38}$ Moreover, $\mathrm{K}_{4}\left[\mathrm{Mo}^{\mathrm{IV}}(\mathrm{CN})_{8}\right] \cdot 2 \mathrm{H}_{2} \mathrm{O}$ itself was found to yield $\mathrm{M}_{\text {sat }} /$ $\chi T_{\max }=1.5(\mathrm{~N} \beta \mathrm{mol}) /\left(\mathrm{cm}^{3} \mathrm{~K}\right)$ in its metastable $S=1$ state resulting from $405 \mathrm{~nm}$ irradiation. A similar formation of the $S$ $=1$ moiety after the irradiation of $\left[\mathrm{Mo}^{\mathrm{IV}}(\mathrm{CN})_{8}\right]^{4-}$ was reported before, ${ }^{39,46-51}$ and we conclude that the observed photomagnetic behavior in $\mathbf{1}$ results from the spin transition centered on the Mo(IV) ion and not the charge-transferinduced photodissociation of the $\left[(\mathrm{NC})_{7} \mathrm{Mo}^{\mathrm{IV}}-\mathrm{CN}\right.$ $\left.\mathrm{Pt}^{\mathrm{IV}}\left(\mathrm{NH}_{3}\right)_{4}-\mathrm{NC}-\mathrm{Mo}^{\mathrm{IV}}(\mathrm{CN})_{7}\right]^{4-}$ unit. In order to further study the behavior of this photomagnetic SBU, attempts to incorporate it into extended coordination networks were made.

\section{STRUCTURAL AND PHOTOMAGNETIC CHARACTERIZATION OF HETEROTRIMETALLIC COMPOUNDS 2 AND 3}

A water solution of a bimetallic SBU $\left[(\mathrm{NC})_{7} \mathrm{Mo}^{\mathrm{IV}}-\mathrm{CN}\right.$ $\left.\mathrm{Pt}^{\mathrm{IV}}\left(\mathrm{NH}_{3}\right)_{4}-\mathrm{NC}-\mathrm{Mo}^{\mathrm{IV}}(\mathrm{CN})_{7}\right]^{4-}$ led to undefined precipitates upon addition of transition metal aqua ions, preventing the synthesis of crystalline coordination networks in the absence of additional ligands. Therefore, our synthesis efforts focused on the use of photomagnetically inactive blocking ligands to support the crystallization process. In the presence of imines (e.g., substituted pyridines, imidazole, and 1,2,4-triazole), the Mo-Pt-Mo SBU decomposed due to the basic environment. Thus, we focused on strongly binding macrocycles, namely 2,13-dimethyl-3,6,9,12,18-pentaazabicyclo-[12.3.1] octadeca1(18),2,12,14,16-pentaene (dpop) and 1,4,8,11-tetraazacyclotetradecane (cyclam). They were both preassembled with $\mathrm{Mn}^{2+}$ and $\mathrm{Cu}^{2+}$ metal ions $\left[\mathrm{Mn}^{\mathrm{II}}(\mathrm{dpop})\left(\mathrm{H}_{2} \mathrm{O}\right)_{2}\right]\left(\mathrm{NO}_{3}\right)_{2}$ and $\left[\mathrm{Cu}^{\mathrm{II}}(\right.$ cyclam $\left.)\left(\mathrm{NO}_{3}\right)\right]\left(\mathrm{NO}_{3}\right)$, respectively, according to the modified literature procedures. ${ }^{52,53}$ Their reactions with the $\mathrm{Mo}-\mathrm{Pt}-\mathrm{Mo}$ SBU solution were performed in the presence of cesium nitrate, which was meant to increase the ionic strength and slow down the crystallization process (details in the SI). This approach resulted in the successful isolation of two heterotrimetallic coordination frameworks: $\left[\mathrm{Mn}^{\mathrm{II}}(\mathrm{dpop})\right]$ $\left[\mathrm{Mn}^{\mathrm{II}}(\mathrm{dpop})\left(\mathrm{H}_{2} \mathrm{O}\right)\right]\left[(\mathrm{NC})_{7} \mathrm{Mo}^{\mathrm{IV}}-\mathrm{CN}-\mathrm{Pt}^{\mathrm{IV}}\left(\mathrm{NH}_{3}\right)_{4}-\mathrm{NC}-\right.$
$\left.\mathrm{Mo}^{\mathrm{IV}}(\mathrm{CN})_{7}\right] \cdot 36 \mathrm{H}_{2} \mathrm{O}$ (2) and $\left[\mathrm{Cu}^{\mathrm{II}}(\mathrm{cyclam})\right]_{2}\left[(\mathrm{NC})_{7} \mathrm{Mo}^{\mathrm{IV}}\right.$ $\left.\mathrm{CN}-\mathrm{Pt}^{\mathrm{IV}}\left(\mathrm{NH}_{3}\right)_{4}-\mathrm{NC}-\mathrm{Mo}^{\mathrm{IV}}(\mathrm{CN})_{7}\right] \cdot 40.89 \mathrm{H}_{2} \mathrm{O}(3)$.

Compound 2 crystallizes in a monoclinic $P 2_{1} / c$ space group. The structure consists of one-dimensional coordination chains formed by cyanide-bridged $\left[\mathrm{Mn}^{\mathrm{II}}(\mathrm{dpop})\right]$ and $\left[(\mathrm{NC})_{7} \mathrm{Mo}^{\mathrm{IV}}\right.$ $\left.\mathrm{CN}-\mathrm{Pt}^{\mathrm{IV}}\left(\mathrm{NH}_{3}\right)_{4}-\mathrm{NC}-\mathrm{Mo}^{\mathrm{IV}}(\mathrm{CN})_{7}\right]$ SBUs along the crystallographic $b$ direction with pendant $\left[\mathrm{Mn}^{\mathrm{II}}(\mathrm{dpop})\left(\mathrm{H}_{2} \mathrm{O}\right)\right]$ arms attached to the octacyanomolybdate moieties (Figure 7 ). The structure is organized by stacking dpop ligands between $\left[\mathrm{Mn}^{\mathrm{II}}(\mathrm{dpop})\right]$ and $\left[\mathrm{Mn}^{\mathrm{II}}(\mathrm{dpop})\left(\mathrm{H}_{2} \mathrm{O}\right)\right]$ units along the $a$ crystallographic direction. Despite the aromaticity of the dpop's pyridine rings, these stacks are not stabilized by $\pi-\pi$

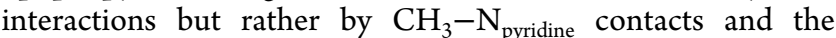
overall hydrophobic character of dpop, as opposed to the rest of the network. Overall, the structure of $\mathbf{2}$ is reminiscent of the framework reported for $\left\{\left[\mathrm{Mn}(\mathrm{dpop})\left(\mathrm{H}_{2} \mathrm{O}\right)\right][\mathrm{Mn}\right.$ (dpop) $][\mathrm{Mo}-$ $\left.\left.(\mathrm{CN})_{8}\right]\right\}_{n} \cdot 4 n \mathrm{H}_{2} \mathrm{O}^{54,55}$ with half of $[\mathrm{Mn}(\text { dpop })]^{2+}$ substituted by $\left[\mathrm{Pt}\left(\mathrm{NH}_{3}\right)_{4}\right]^{4+}$ units. Charge balance enforces the simultaneous elimination of the same number of $[\mathrm{Mn}(\mathrm{dpop})$ $\left.\left(\mathrm{H}_{2} \mathrm{O}\right)\right]^{2+}$ moieties. Effectively, two sterically demanding units are substituted by a small $\left[\mathrm{Pt}\left(\mathrm{NH}_{3}\right)_{4}\right]^{4+}$ fragment, which drastically increases the volume of the water-filled cavities in the structure. These cavities occupy approximately $40 \%$ of the unit cell volume (Figure S10). It was possible to identify electron density corresponding to 35 water molecules per formula unit in the model. Additional $\mathrm{H}_{2} \mathrm{O}$ molecules can be postulated to account for the remaining $45 \AA^{3}$ void volume (using a $1.2 \AA$ probe radius ${ }^{56}$ ).

Magnetic studies of $\mathbf{2}$ render it as a typical paramagnet presenting only weak antiferromagnetic interactions, giving a $\chi T$ value of $8.81 \mathrm{~cm}^{3} \mathrm{~K} \mathrm{~mol}{ }^{-1}$ at $250 \mathrm{~K}$. The thermal dependence of $\chi T$ (Figure $8 \mathrm{a}$ ) was fitted ${ }^{44}$ to eq 3

$$
\chi T=\frac{\chi_{\text {calc }}{ }^{T}}{1-\left(z J / N_{\mathrm{A}} \mu_{\mathrm{B}}{ }^{2}\right) \chi_{\text {calc }}}
$$

resulting in $z J=-0.02(1) \mathrm{cm}^{-1}$ and $g=2.01(2)$. (Please note that $\chi T$ in eq 3 is a function of $g$ as presented in eq 1.) For the details of the fitting model, see Figure S11 in the SI. This is in accord with the field dependence of magnetization, resembling the Brillouin function and reaching $9.9 \mathrm{~N} \beta$ at $7 \mathrm{~T}$ (Figure S12), which is very close to $10 \mathrm{~N} \beta$ expected for two noninteracting $S$ 
a)

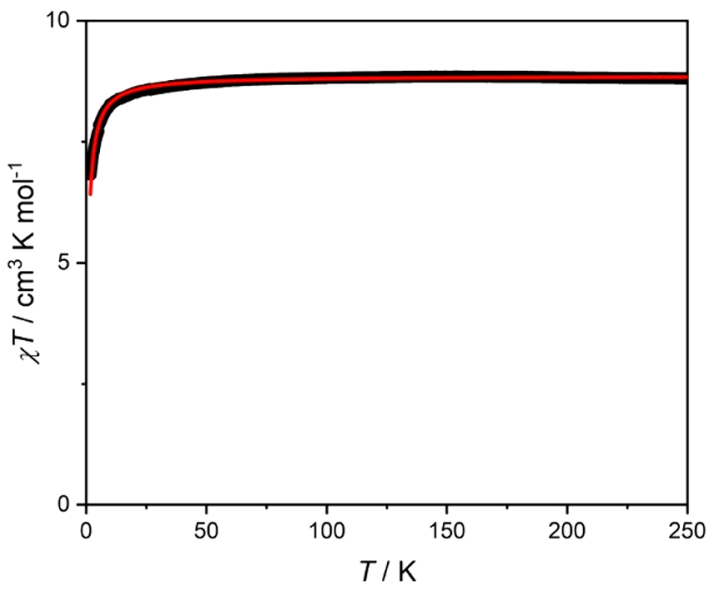

b)

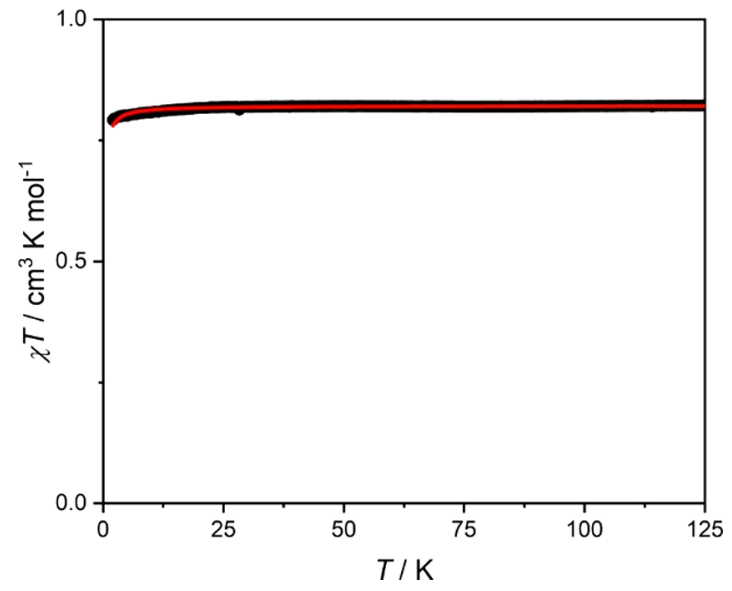

Figure 8. $\chi T(T)$ dependence for (a) 2 and (b) 3 under $H=0.1 \mathrm{~T}$. Red lines present the best fits to eq 3 .

$=5 / 2$ spins. Surprisingly, no photomagnetic effect was observed for 2 upon irradiation with 585, 530, or $473 \mathrm{~nm}$ light at $10 \mathrm{~K}$. The lack of photomagnetic behavior may be caused by a very strong absorption of the $\left[\mathrm{Mn}^{\mathrm{II}}(\mathrm{dpop})(\mathrm{NC})_{2}\right]$ unit in this energy range, which obstructs the weak photoactive $\mathrm{d}-\mathrm{d}$ transitions centered at $\mathrm{Mo}^{\mathrm{IV}}$. (See Figure $\mathrm{S} 13$ for a comparison of the UV-vis spectra of $\left[\mathrm{Mn}^{\mathrm{II}}(\mathrm{dpop})\left(\mathrm{H}_{2} \mathrm{O}\right)_{2}\right]$ $\left(\mathrm{NO}_{3}\right)_{2}$ starting material and target compound 2.)

The unit cell of compound 3 represents a triclinic crystal system in the $P \overline{1}$ space group. It is organized in a $2 \mathrm{D}$ honeycomb network (Figure 9), where copper(II) and platinum(IV) ions lie on the (101) plane, while the rest of the atoms are slightly shifted out of the plane. As a result, compound 3 forms a crystal lattice similar to the series of porous $\left[\mathrm{Ni}^{\mathrm{II}}(\text { cyclam })\right]_{3}\left[\mathrm{~W}^{\mathrm{V}}(\mathrm{CN})_{8}\right]_{2} \cdot n$ solv networks, ${ }^{17,57,58}$ with one $\left[\mathrm{Ni}^{\mathrm{II}}(\right.$ cyclam $\left.)\right]$ moiety in the formula unit replaced by $\left[\mathrm{Pt}^{\mathrm{IV}}\left(\mathrm{NH}_{3}\right)_{4}\right]$. Note that the difference in the charge of $\left[\mathrm{Pt}^{\mathrm{IV}}\left(\mathrm{NH}_{3}\right)_{4}\right]^{4+}$ is balanced by the change in the oxidation state of octacyanometallate moieties. All of these differences result in $42 \%$ larger cavity volume in 3 compared to $\left[\mathrm{Ni}^{\mathrm{II}}(\text { cyclam })\right]_{3}\left[\mathrm{WV}(\mathrm{CN})_{8}\right]_{2} \cdot n$ solv $\left(1.2 \AA\right.$ probe radius, ${ }^{56}$ see Figure S16), similar to 2 and $\left\{\left[\mathrm{Mn}(\right.\right.$ dpop $\left.)\left(\mathrm{H}_{2} \mathrm{O}\right)\right][\mathrm{Mn}$ (dpop) $\left.]\left[\mathrm{Mo}(\mathrm{CN})_{8}\right]\right\}_{n} \cdot 4 n \mathrm{H}_{2} \mathrm{O} .{ }^{54,55}$ Copper(II) centers in the framework show a strong Jahn-Teller effect, with the average equatorial $\mathrm{Cu}-\mathrm{N}_{\text {cyclam }}$ bond length of 2.027(8) $\AA$ and the average axial $\mathrm{Cu}-\mathrm{N}_{\text {cyanide }}$ bond length of 2.451(3) $\AA$. This observation is similar to the previously reported networks based on $[\mathrm{Cu}(\text { cyclam })]^{2+}$ and octacyanometalates. ${ }^{59-63}$



Figure 9. Coordination layer in $\mathbf{3}$ as seen along the $a$ axis. White, Pt; green, $\mathrm{Mo}$; orange, $\mathrm{Cu}$; blue, $\mathrm{N}$; gray, $\mathrm{C}$. Hydrogen atoms and crystallization water molecules were omitted for clarity.

The thermal dependence of the magnetic susceptibility of 3 (Figure $8 \mathrm{~b}$ ) was fitted to eq 3, yielding $g=2.09(2)$ and $z J=$ $-0.07(1) \mathrm{cm}^{-1}$, assuming one relatively well isolated copper(II) center. The antiferromagnetic interaction probably results from dipole-dipole interactions between copper(II) cations forming a chain along the crystallographic $b$ axis. This $\chi T(T)$ dependence is in line with the field dependence of magnetization at $1.8 \mathrm{~K}$ (Figure S17), reaching $2.0 \mathrm{~N} \beta$ at $7 \mathrm{~T}$, slightly lower than $2.18 \mathrm{~N} \beta$ expected for two $g=2.09 \mathrm{Cu}$ (II) centers. The small difference is likely to result from weak antiferromagnetic interactions, not enabling complete saturation of the magnetization at this temperature. The value of the $g$ factor determined from magnetic measurements is in line with the X-band EPR spectrum for 3, which can be reproduced by assuming $g_{z}=2.20$ and $g_{x y}=2.05$ (Figure S18). ${ }^{64}$

Light irradiation of compound $3(\lambda=450 \mathrm{~nm}, 10 \mathrm{~K}, 0.1 \mathrm{~T})$ leads to a small but distinct increase in the $\chi T$ product of around $2.5 \%$ (Figure S19). This small change is in line with the temperature dependence of magnetic susceptibility, which shows consistently higher magnetization level after irradiation as compared to that of the initial state (Figure 10). The photoinduced transition is reversible, with the compound relaxing thermally to the initial state after $1 \mathrm{~h}$ of thermal relaxation at $250 \mathrm{~K}$. The photomagnetic behavior of compound 3 may originate from three different phenomena: (i) charge transfer within $\mathrm{Mo}(\mathrm{IV})-\mathrm{Pt}(\mathrm{IV})$ pairs $^{30,65}$ of the $\mathrm{Mo}-\mathrm{Pt}-\mathrm{Mo}$ $\mathrm{SBU}$, (ii) charge transfer between $\mathrm{Mo}$ (IV) and $\mathrm{Cu}(\mathrm{II}),{ }^{50,66}$ and (iii) a spin transition located solely at Mo(IV)..$^{39,46-51}$ The first mechanism (i) is unlikely to occur, as it was not observed in $\mathbf{1}$, and the $450 \mathrm{~nm}$ irradiation wavelength is far from the maximum of the Mo(IV)-Pt(IV) MMCT band (Figure S20). The electron transfer from octacyanomolybdate(IV) to copper(II) (ii) is not expected in the discussed material, as no additional MMCT band could be observed in the UV-vis spectrum as compared to starting material $\mathbf{1}$. This might be caused by $\mathrm{Mo}^{\mathrm{IV}}-\mathrm{CN}-\mathrm{Cu}^{\mathrm{II}}$ cyanide bridge elongation due to the Jahn-Teller effect, which in turn prevents an efficient charge transfer along this pathway. To further exclude photoinduced electron transfer involving $\mathrm{Cu}^{\mathrm{II}}$, we have performed EPR measurements at $10 \mathrm{~K}$ with $450 \mathrm{~nm}$ light irradiation. At first, these photoexperiments led to the decrease in the $\mathrm{Cu}^{\mathrm{II}}$ signal after $5 \mathrm{~min}$ of irradiation (Figure 11) due to heating effects 


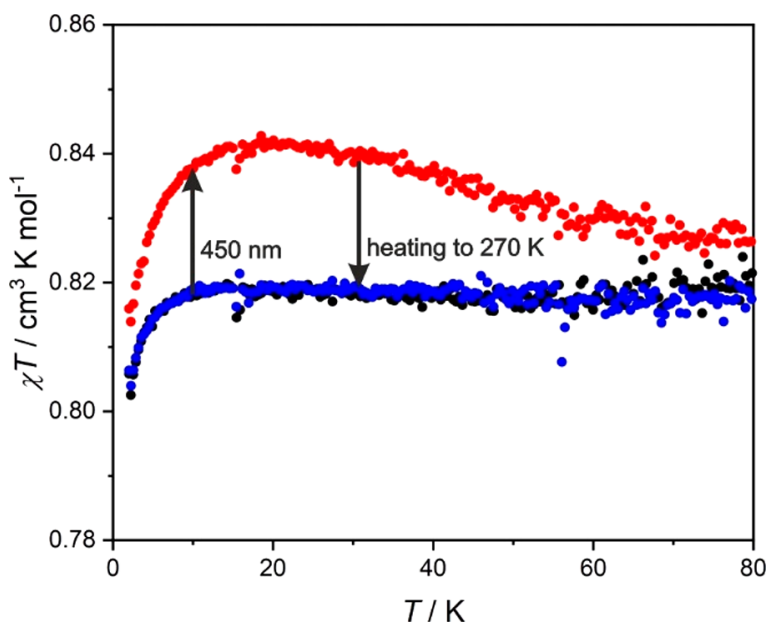

Figure 10. $\chi T(T)$ dependence of 3 before light irradiation (black points), after $450 \mathrm{~nm}$ light irradiation (red points), and after thermal relaxation at $250 \mathrm{~K}$ (blue points) under $H=0.1 \mathrm{~T}$.



Figure 11. EPR spectra recorded for 3 at $10 \mathrm{~K}$ before $450 \mathrm{~nm}$ light irradiation (initial), after 5 and $30 \mathrm{~min}$ of continuous irradiation, and after turning the irradiation light off. The decrease in the $\mathrm{Cu}^{\mathrm{II}}$ signal under light irradiation is interpreted as a thermal effect only. (It vanishes completely after turning the light off.)

(laser diode power $P \approx 70 \mathrm{~mW}$ ). No further changes are observed upon an additional $30 \mathrm{~min}$ of constant irradiation. After turning the light off, the initial spectrum is fully restored, confirming that the only light-induced changes in the $\mathrm{Cu}^{\text {II }}$ signal are related to sample heating effects. Therefore, the $\mathrm{Mo}^{\text {IV }}$ spin state changing from $S=0$ to 1 accompanied by $\mathrm{CN}$ ligand photodissociation (iii) seems to be the most plausible explanation of the photoinduced magnetization change in 3 , in accord with the observation of a photomagnetic response only after irradiation using the same wavelength as in SBU 1. The possibility of $\mathrm{Mo}^{\mathrm{IV}}-\mathrm{CN}$ bond breaking ${ }^{38}$ would also explain the low irradiation efficiency, as water-filled crystal pores do not offer much space to accommodate dissociated cyanide. The lack of an EPR signal for $S=1 \mathrm{Mo}^{\mathrm{IV}}$ after the irradiation of 3 at low temperature is not unexpected, as triplet states are often considered to be "EPR silent" exceeding the $\mathrm{X}$-band energy range $\left(\sim 0.3 \mathrm{~cm}^{-1}\right)$, which is the case for highly anisotropic $\left[\mathrm{Mo}^{\mathrm{IV}}(\mathrm{CN})_{7}\right]^{3-}\left(D>10 \mathrm{~cm}^{-1}\right) .^{38}$ However, an unambiguous determination of the mechanism underlying the photomagnetic changes in 3 would require additional studies using photocrystallography at liquid helium temperature and/or X-ray magnetic circular dichroism (XMCD), which will be performed in the future.

Because of the high crystallization water content observed in both networks 2 and 3, we performed dehydration attempts on these two frameworks, which may lead to the appearance of photomagnetic behavior or its strong enhancement. ${ }^{19}$ However, both samples lose crystallinity upon dehydration (Figures S22 and S23), despite the presence of a wide plateau in the thermogravimetric curves (Figures S24 and S25). This observation is especially striking for 3 , which is similar to the $\left[\mathrm{Ni}^{\mathrm{II}}(\mathrm{cyclam})\right]_{3}\left[\mathrm{~W}^{\mathrm{V}}(\mathrm{CN})_{8}\right]_{2} \cdot n$ solv framework showing good stability during dehydration-rehydration cycles. ${ }^{57,58}$ The loss of stability should not be related to $\mathrm{Cu}^{\mathrm{II}}$ centers, in which the transformation of a related $1-\mathrm{D}$ C P $\left\{\left[\mathrm{Cu}^{\mathrm{II}}(\mathrm{cyclam})\right]_{3}\left[\mathrm{~W}^{\mathrm{V}}(\mathrm{CN})_{8}\right]_{2} \cdot 5 \mathrm{H}_{2} \mathrm{O}\right\}_{n}$ to $\left\{\left[\mathrm{Cu}^{\mathrm{II}}(\text { cyclam })\right]_{3}\left[\mathrm{~W}^{\mathrm{V}}(\mathrm{CN})_{8}\right]_{2}\right\}_{n}$ is a single-crystal-singlecrystal process. ${ }^{59}$ Therefore, we propose that in the case of $\mathbf{2}$ and 3 the lack of thermal stability may originate from the decomposition of $\mathrm{Mo}-\mathrm{Pt}-\mathrm{Mo}$ SBUs involving $\mathrm{CN}-\mathrm{Pt}$ bond dissociation or $\mathrm{NH}_{3}$ elimination.

\section{CONCLUSIONS}

We have successfully isolated and characterized a stable hexadekacyanometallate $\mathrm{SBU} \quad\left[(\mathrm{NC})_{7} \mathrm{Mo}^{\mathrm{IV}}-\mathrm{CN}-\mathrm{Pt}^{\mathrm{IV}}\left(\mathrm{NH}_{3}\right)_{4}\right.$ $\left.\mathrm{NC}-\mathrm{Mo}^{\mathrm{IV}}(\mathrm{CN})_{7}\right]^{4-}$ in the form of $\left(\mathrm{dppipH}_{2}\right)_{2}\left[(\mathrm{NC})_{7} \mathrm{Mo}^{\mathrm{IV}}-\right.$ $\left.\mathrm{CN}-\mathrm{Pt}^{\mathrm{IV}}\left(\mathrm{NH}_{3}\right)_{4}-\mathrm{NC}-\mathrm{Mo}^{\mathrm{IV}}(\mathrm{CN})_{7}\right] \cdot 15 \mathrm{H}_{2} \mathrm{O}$ (1). This compound has a second-order phase transition related to the cation's conformational change. It was demonstrated that $\left[(\mathrm{NC})_{7} \mathrm{Mo}^{\mathrm{IV}}-\mathrm{CN}-\mathrm{Pt}^{\mathrm{IV}}\left(\mathrm{NH}_{3}\right)_{4}-\mathrm{NC}-\mathrm{Mo}^{\mathrm{IV}}(\mathrm{CN})_{7}\right]^{4-}$ itself shows photomagnetic behavior in the solid state after $450 \mathrm{~nm}$ light irradiation, which most probably originates from the spin transition at the molybdenum(IV) center following the $\mathrm{CN}$ photodissociation. This SBU is stable in aqueous solution, which in turn enabled its use in the preparation of heterotrimetallic coordination polymers 2 (coordination chain) and 3 (coordination layers) containing large waterfilled cavities. Moreover, $\left[\mathrm{Cu}^{\mathrm{II}}(\text { cyclam })\right]_{2}\left[(\mathrm{NC})_{7} \mathrm{Mo}^{\mathrm{IV}}-\mathrm{CN}\right.$ $\left.\mathrm{Pt}^{\mathrm{IV}}\left(\mathrm{NH}_{3}\right)_{4}-\mathrm{NC}-\mathrm{Mo}^{\mathrm{IV}}(\mathrm{CN})_{7}\right] \cdot 40.89 \mathrm{H}_{2} \mathrm{O}(3)$ retains the photomagnetic functionality of the SBU. Thus, MoPtMo can be considered to be a bimetallic photomagnetic secondary building unit that is useful in the synthesis of highly sophisticated heterotrimetallic frameworks, simplifying the synthesis of this demanding class of compounds. ${ }^{67-72}$ It can also be easily modified by the substitution of $\mathrm{NH}_{3}$ at the $\mathrm{Pt}$ center with other $\mathrm{N}$-donor ligands such as ethylendiamine ${ }^{27}$ and imidazole. ${ }^{73}$ This line of research is currently being tested in our laboratories.

\section{ASSOCIATED CONTENT}

\section{Supporting Information}

The Supporting Information is available free of charge at https://pubs.acs.org/doi/10.1021/acs.inorgchem.0c00737.

Experimental procedures including synthesis details, IR and UV-vis spectra, PXRD patterns, DSC and TGA plots, and supplementary structural diagrams and magnetic measurements (PDF)

\section{Accession Codes}

CCDC 1986059-1986062 contain the supplementary crystallographic data for this paper. These data can be obtained free of charge via www.ccdc.cam.ac.uk/data_request/cif, or by 
emailing data_request@ccdc.cam.ac.uk, or by contacting The Cambridge Crystallographic Data Centre, 12 Union Road, Cambridge CB2 1EZ, UK; fax: +44 1223336033.

\section{AUTHOR INFORMATION}

\section{Corresponding Authors}

Michal Magott - Faculty of Chemistry, Jagiellonian University, 30-387 Kraków, Poland; () orcid.org/0000-0002-4566-2636; Email: michal.magott@uj.edu.pl

Dawid Pinkowicz - Faculty of Chemistry, Jagiellonian University, 30-387 Krakow, Poland; 이잉.org/0000-00029958-3116; Email: dawid.pinkowicz@uj.edu.pl

\section{Authors}

Marcin Sarewicz - Faculty of Biochemistry, Biophysics and Biotechnology, Department of Molecular Biophysics, Jagiellonian University, 30-387 Kraków, Poland; 이이.org/0000-00016813-5997

Szymon Buda - Faculty of Chemistry, Jagiellonian University, 30-387 Kraków, Poland; ㅇ orcid.org/0000-0003-3711-3570

Complete contact information is available at:

https://pubs.acs.org/10.1021/acs.inorgchem.0c00737

\section{Notes}

The authors declare no competing financial interest.

\section{ACKNOWLEDGMENTS}

This work was financed by the Polish Ministry of Science and Higher Education within the Diamond Grant project (0192/ DIA/2017/46) and by the Polish National Science Centre within Sonata Bis $6(2016 / 22 / E / S T 5 / 00055)$. The authors gratefully acknowledge Prof. Barbara Sieklucka and Prof. Robert Podgajny for inspiring this work and Prof. Artur Osyczka for providing access to the EPR facility of the Faculty of Biochemistry, Biophysics and Biotechnology, Department of Molecular Biophysics.

\section{REFERENCES}

(1) Sarkisov, L.; Martin, R. L.; Haranczyk, M.; Smit, B. On the Flexibility of Metal-Organic Frameworks. J. Am. Chem. Soc. 2014, 136, 2228-2231.

(2) Taylor, M. K.; Runčevski, T.; Oktawiec, J.; Gonzalez, M. I.; Siegelman, R. L.; Mason, J. A.; Ye, J.; Brown, C. M.; Long, J. R. Tuning the Adsorption-Induced Phase Change in the Flexible MetalOrganic Framework Co(bdp). J. Am. Chem. Soc. 2016, 138, 1501915026

(3) Furukawa, H.; Cordova, K. E.; O’Keeffe, M.; Yaghi, O. M. The Chemistry and Applications of Metal-Organic Frameworks. Science 2013, 341, 1230444.

(4) Zhou, H.-C.; Kitagawa, S. Metal-Organic Frameworks (MOFs). Chem. Soc. Rev. 2014, 43, 5415-5418.

(5) Cui, Y.; Li, B.; He, H.; Zhou, W.; Chen, B.; Qian, G. MetalOrganic Frameworks as Platforms for Functional Materials. Acc. Chem. Res. 2016, 49, 483-493.

(6) Li, B.; Wen, H.-M.; Cui, Y.; Zhou, W.; Qian, G.; Chen, B. Emerging Multifunctional Metal-Organic Framework Materials. Adv. Mater. 2016, 28, 8819-8860.

(7) Coronado, E.; Mínguez Espallargas, G. Dynamic Magnetic MOFs. Chem. Soc. Rev. 2013, 42, 1525-1539 February 21.

(8) Mínguez Espallargas, G.; Coronado, E. Magnetic Functionalities in MOFs: From the Framework to the Pore. Chem. Soc. Rev. 2018, 47, 533-557.

(9) Thorarinsdottir, A. E.; Harris, T. D. Metal-Organic Framework Magnets. Chem. Rev. 2020. DOI: 10.1021/acs.chemrev.9b00666
(10) Pedersen, K. S.; Sørensen, M. A.; Bendix, J. FluorideCoordination Chemistry in Molecular and Low-Dimensional Magnetism. Coord. Chem. Rev.; Elsevier September 1, 2015; pp 1-21.

(11) McInnes, E. J. L.; Timco, G. A.; Whitehead, G. F. S.; Winpenny, R. E. P. Heterometallic Rings: Their Physics and Use as Supramolecular Building Blocks. Angew. Chem., Int. Ed. 2015, 54, 14244-14269.

(12) Grochala, W. Silverland: The Realm of Compounds of Divalent Silver-and Why They Are Interesting. J. Supercond. Novel Magn. 2018, 31, 737-752.

(13) Clemente-León, M.; Coronado, E.; Martí-Gastaldo, C.; Romero, F. M. Multifunctionality in Hybrid Magnetic Materials Based on Bimetallic Oxalate Complexes. Chem. Soc. Rev. 2011, 40, 473-497 February.

(14) Sieklucka, B.; Pinkowicz, D. . Molecular Magnetic Materials: Concepts and Applications; Wiley-VCH Verlag GmbH \& Co. KGaA: Weinheim, Germany, 2017.

(15) Pedersen, K. S.; Bendix, J.; Clérac, R. Single-Molecule Magnet Engineering: Building-Block Approaches. Chem. Commun. 2014, 50, 4396-4415.

(16) Pinkowicz, D.; Podgajny, R.; Gaweł, B.; Nitek, W.; Łasocha, W.; Oszajca, M.; Czapla, M.; Makarewicz, M.; BaŁanda, M.; Sieklucka, B. Double Switching of a Magnetic Coordination Framework through Intraskeletal Molecular Rearrangement. Angew. Chem., Int. Ed. 2011, 50, 3973-3977.

(17) Nowicka, B.; Rams, M.; Stadnicka, K.; Sieklucka, B. Reversible Guest-Induced Magnetic and Structural Single-Crystal-to-SingleCrystal Transformation in Microporous Coordination Network $\left\{[\mathrm{Ni}(\text { cyclam })]_{3}\left[\mathrm{~W}(\mathrm{CN})_{8}\right]_{2}\right\}_{n}$. Inorg. Chem. 2007, 46, 8123-8125.

(18) Jeon, I.-R.; Negru, B.; Van Duyne, R. P.; Harris, T. D. A 2D Semiquinone Radical-Containing Microporous Magnet with SolventInduced Switching from $T_{\mathrm{c}}=26$ to $80 \mathrm{~K}$. J. Am. Chem. Soc. 2015, 137, 15699-15702.

(19) Magott, M.; Reczyński, M.; Gaweł, B.; Sieklucka, B.; Pinkowicz, D. A Photomagnetic Sponge: High-Temperature Light-Induced Ferrimagnet Controlled by Water Sorption. J. Am. Chem. Soc. 2018, $140,15876-15882$.

(20) Kosaka, W.; Liu, Z.; Zhang, J.; Sato, Y.; Hori, A.; Matsuda, R.; Kitagawa, S.; Miyasaka, H. Gas-Responsive Porous Magnet Distinguishes the Electron Spin of Molecular Oxygen. Nat. Commun. 2018, 9, 9.

(21) Ohba, M.; Yoneda, K.; Agustí, G.; Muñoz, M. C.; Gaspar, A. B.; Real, J. A.; Yamasaki, M.; Ando, H.; Nakao, Y.; Sakaki, S.; Kitagawa, S. Bidirectional Chemo-Switching of Spin State in a Microporous Framework. Angew. Chem., Int. Ed. 2009, 48, 4767-4771.

(22) Muñoz-Lara, F. J.; Gaspar, A. B.; Muñoz, M. C.; Arai, M.; Kitagawa, S.; Ohba, M.; Real, J. A. Sequestering Aromatic Molecules with a Spin-Crossover FeII Microporous Coordination Polymer. Chem. - Eur. J. 2012, 18, 8013-8018.

(23) Das, M. C.; Xiang, S.; Zhang, Z.; Chen, B. Functional Mixed Metal-Organic Frameworks with Metalloligands. Angew. Chem., Int. Ed. 2011, 50, 10510-10520.

(24) Grancha, T.; Ferrando-Soria, J.; Castellano, M.; Julve, M.; Pasán, J.; Armentano, D.; Pardo, E. Oxamato-Based Coordination Polymers: Recent Advances in Multifunctional Magnetic Materials. Chem. Commun. 2014, 50, 7569-7585.

(25) Tranchemontagne, D. J.; Mendoza-Cortés, J. L.; O’Keeffe, M.; Yaghi, O. M. Secondary Building Units, Nets and Bonding in the Chemistry of Metal-Organic Frameworks. Chem. Soc. Rev. 2009, 38, 1257-1283.

(26) Kalmutzki, M. J.; Hanikel, N.; Yaghi, O. M. Secondary Building Units as the Turning Point in the Development of the Reticular Chemistry of MOFs. Sci. Adv. 2018, 4, No. eaat9180.

(27) Podgajny, R.; Dromzée, Y.; Kruczala, K.; Sieklucka, B. Metal Metal Interactions in Bent Cyano-Bridged Trinuclear Octacyanomolybdate(IV)-Platinum(IV) Complexes. Polyhedron 2001, 20, 685-694.

(28) Zhou, M.; Pfennig, B. W.; Steiger, J.; Van Engen, D.; Bocarsly, A. B. Multielectron Transfer and Single-Crystal X-Ray Structure of a 
Trinuclear Cyanide-Bridged Platinum-Iron Species. Inorg. Chem. 1990, 29, 2456-2460.

(29) Pfennig, B. W.; Bocarsly, A. B. Photoinduced Multielectron Charge Transfer in the Polymetallic Intervalent Complex $\left[(\mathrm{NC})_{5} \mathrm{Fe}-\right.$ $\left.\mathrm{CN}-\mathrm{Pt}\left(\mathrm{NH}_{3}\right)_{4}-\mathrm{NC}-\mathrm{Fe}(\mathrm{CN})_{5}\right]^{4-}$ and Related Species. Coord. Chem. Rev. 1991, 111, 91-96.

(30) Pfennig, B. W.; Bocarsly, A. B. Surface-Attached $\left[(\mathrm{NC})_{5} \mathrm{Fe}-\right.$ (CN) $\left.\mathrm{Pt}\left(\mathrm{NH}_{3}\right)_{4}(\mathrm{NC}) \mathrm{Fe}(\mathrm{CN})_{5}\right]^{4-}$ : A Study in the Electrochemical and Photochemical Control of Surface Morphology. Inorg. Chem. 1991, 30, 666-672.

(31) Ghosh, S. K.; Ribas, J.; Bharadwaj, P. K. Characterization of 3D Metal-Organic Frameworks Formed through Hydrogen Bonding Interactions of 2-D Networks with Rectangular Voids by $\mathrm{Co}^{\mathrm{II}}$ - and $\mathrm{Ni}^{\mathrm{II}}$-Pyridine-2,6-Dicarboxylate and 4,4'-Bipyridine or 1,2-Di(Pyridyl)Ethylene. Cryst. Growth Des. 2005, 5, 623-629.

(32) Jin, A. P.; Chen, Z. W.; Wang, M. S.; Guo, G. C. $\left[\mathrm{Zn}(\mathrm{OOCH})_{2}\left(4,4^{\prime} \text {-Bipyridine }\right)\right]_{\mathrm{n}}$ : A Metal-Organic-Framework (MOF) with X-Ray-Induced Photochromic Behaviour at Room Temperature. Dyes Pigm. 2019, 163, 656-659.

(33) Peedikakkal, A. M. P.; Vittal, J. J. Structural Transformations of $\mathrm{Pb}$ (II)-trans-1,2-Bis(4'-Pyridyl)Ethene Coordination Polymers in Solution. Cryst. Growth Des. 2011, 11, 4697-4703.

(34) Foo, M. L.; Matsuda, R.; Hijikata, Y.; Krishna, R.; Sato, H.; Horike, S.; Hori, A.; Duan, J.; Sato, Y.; Kubota, Y.; Takata, M.; Kitagawa, S. An Adsorbate Discriminatory Gate Effect in a Flexible Porous Coordination Polymer for Selective Adsorption of $\mathrm{CO}_{2}$ over $\mathrm{C}_{2} \mathrm{H}_{2}$. J. Am. Chem. Soc. 2016, 138, 3022-3030.

(35) Andruh, M. Heterotrimetallic Complexes in Molecular Magnetism. Chem. Commun. 2018, 54, 3559-3577.

(36) Nowicka, B.; Reczyński, M.; Nitek, W.; Sieklucka, B. Cyclams with Varied Degree of Protonation in the Assemblies with Cyano Complexes of Mo and W. Polyhedron 2012, 47, 73-78.

(37) Llunell, M.; Casanova, D.; Cirera, J.; Alemany, P.; Alvarez, S. SHAPE, Version 2.1.; University of Barcelona: Barcelona, Spain, 2013; p 2103.

(38) Qi, X.; Pillet, S.; de Graaf, C.; Magott, M.; Bendeif, E. E.; Guionneau, P.; Rouzières, M.; Marvaud, V.; Stefańczyk, O.; Pinkowicz, D.; Mathonière, C. Photoinduced Mo-CN Bond Breakage in Octacyanomolybdate Leading to Spin Triplet Trapping. Angew. Chem., Int. Ed. 2020, 59, 3117-3121.

(39) Magott, M.; Stefańczyk, O.; Sieklucka, B.; Pinkowicz, D. Octacyanidotungstate(IV) Coordination Chains Demonstrate a Light-Induced Excited Spin State Trapping Behavior and Magnetic Exchange Photoswitching. Angew. Chem., Int. Ed. 2017, 56, 1328313287.

(40) Hendrickx, M. F. A.; Mironov, V. S.; Chibotaru, L. F.; Ceulemans, A. Assignment of the Electronic Spectra of $\left[\mathrm{Mo}(\mathrm{CN})_{8}\right]^{4-}$ and $\left[\mathrm{W}(\mathrm{CN})_{8}\right]^{4-}$ by $\mathrm{Ab}$ Initio Calculations. Inorg. Chem. 2004, 43, $3142-3150$

(41) Whitlock, H. W. Tricyclo[4.4.0.03.8]Decane. J. Am. Chem. Soc. 1962, 84, 3412-3413.

(42) Lai, L. L.; Wu, C. H.; Lu, K. L.; Wen, Y. S.; Liu, Y. H.; Wang, Y.; Cheng, K. L.; Soldatov, D. V.; Yu, Z.; Yu, K. Polypseudorotaxane Architecture of poly-bis[4-(N-benzyl-pyridinium)piperazine-hexa-thiocyanato-di-cadmium(II) with 2-D Honeycomb-like $\left[\mathrm{Cd}(\mathrm{SCN})_{3}\right]_{n}{ }^{n-}$ Anionic Polymeric Framework. CrystEngComm 2007, 9, 345-349.

(43) Jennifer, S. J.; Jana, A. K. Influence of Pyrazine/Piperazine Based Guest Molecules in the Crystal Structures of Uranyl Thiophene Dicarboxylate Coordination Polymers: Structural Diversities and Photocatalytic Activities for the Degradation of Organic Dye. Cryst. Growth Des. 2017, 17, 5318-5329.

(44) Chilton, N. F.; Anderson, R. P.; Turner, L. D.; Soncini, A.; Murray, K. S. PHI: A Powerful New Program for the Analysis of Anisotropic Monomeric and Exchange-Coupled Polynuclear $d$ - and $f$ block Complexes. J. Comput. Chem. 2013, 34, 1164-1175.

(45) Goldfarb, D.; Stoll, S. Modern EPR Spectroscopy.; John Wiley \& Sons, 2018.

(46) Brossard, S.; Volatron, F.; Lisnard, L.; Arrio, M. A.; Catala, L.; Mathonière, C.; Mallah, T.; Cartier Dit Moulin, C.; Rogalev, A.;
Wilhelm, F.; Smekhova, A.; Sainctavit, P. Investigation of the Photoinduced Magnetization of Copper Octacyanomolybdates Nanoparticles by X-Ray Magnetic Circular Dichroism. J. Am. Chem. Soc. 2012, 134, 222-228.

(47) Bridonneau, N.; Long, J.; Cantin, J. L.; Von Bardeleben, J.; Pillet, S.; Bendeif, E. E.; Aravena, D.; Ruiz, E.; Marvaud, V. First Evidence of Light-Induced Spin Transition in Molybdenum(IV). Chem. Commun. 2015, 51, 8229-8232.

(48) Korzeniak, T.; Pinkowicz, D.; Nitek, W.; Dańko, T.; Pełka, R.; Sieklucka, B. Photoswitchable $\mathrm{Cu}_{4}{ }_{4} \mathrm{Mo}^{\mathrm{IV}}$ and $\mathrm{Cu}_{2}{ }_{2} \mathrm{Mo}^{\mathrm{IV}}$ CyanidoBridged Molecules. Dalton Trans. 2016, 45, 16585-16595.

(49) Korzeniak, T.; Jankowski, R.; Kozieł, M.; Pinkowicz, D.; Sieklucka, B. Reversible Single-Crystal-to-Single-Crystal Transformation in Photomagnetic Cyanido-Bridged $\mathrm{Cd}_{4} \mathrm{M}_{2}$ Octahedral Molecules. Inorg. Chem. 2017, 56, 12914-12919.

(50) Stefańczyk, O.; Pełka, R.; Majcher, A. M.; Mathonière, C.; Sieklucka, B. Irradiation Temperature Dependence of the Photomagnetic Mechanisms in a Cyanido-Bridged $\mathrm{Cu}_{2}{ }_{2} \mathrm{Mo}^{\mathrm{IV}}$ Trinuclear Molecule. Inorg. Chem. 2018, 57, 8137-8145.

(51) Korzeniak, T.; Sasmal, S.; Pinkowicz, D.; Sieklucka, B. The Photomagnetic Effect in 2-D Cyanido-Bridged Coordination Polymer $[\mathrm{Cu}(\text { aepa })]_{10}\left[\mathrm{Mo}(\mathrm{CN})_{8}\right]_{5} \cdot 30 \mathrm{H}_{2} \mathrm{O}$. New J. Chem. 2018, 42, 1700917015.

(52) Jiménez-Sandoval, O.; Ramírez-Rosales, D.; Rosales-Hoz, M. D. J.; Sosa-Torres, M. E.; Zamorano-Ulloa, R. Magnetostructural Behaviour of the Complex $\left[\mathrm{MnL}\left(\mathrm{H}_{2} \mathrm{O}\right)_{2}\right] \mathrm{Cl}_{2} \cdot 4 \mathrm{H}_{2} \mathrm{O}$ at Variable Temperature Studied by Electron Spin Resonance $(\mathrm{L}=2,13$ Dimethyl-3,6,9,12,18-Pentaazabicyclo[12.3.1] Octadeca1(18),2,12,14,16- Pentaene). J. Chem. Soc., Dalton Trans. 1998, No. 10, 1551-1556.

(53) Pérez-Toro, I.; Domínguez-Martín, A.; Choquesillo-Lazarte, D.; Vílchez-Rodríguez, E.; González-Pérez, J. M.; Castiñeiras, A.; NiclósGutiérrez, J. Lights and Shadows in the Challenge of Binding Acyclovir, a Synthetic Purine-like Nucleoside with Antiviral Activity, at an Apical-Distal Coordination Site in Copper(II)-Polyamine Chelates. J. Inorg. Biochem. 2015, 148, 84-92.

(54) Zhang, H.; Xue, C.; Shi, J.; Liu, H.; Dong, Y.; Zhao, Z.; Zhang, D.; Jiang, J. Coordination Field Tuned Cyanide-Bridged Polynuclear and One-Dimensional Heterobimetallic Complexes: Synthesis, Crystal Structures, and Magnetic Properties. Cryst. Growth Des. 2016, 16, 5753-5761.

(55) Rombaut, G.; Golhen, S.; Ouahab, L.; Mathonière, C.; Kahn, O. Structural and Photomagnetic Studies of a 1-D Bimetallic Chain $\left[\mathrm{Mn}_{2}{ }_{2}(\mathrm{~L})_{2}\left(\mathrm{H}_{2} \mathrm{O}\right)\right]\left[\mathrm{Mo}^{\mathrm{IV}}(\mathrm{CN})_{8}\right] \cdot 5 \mathrm{H}_{2} \mathrm{O}(\mathrm{L}=$ macrocycle $):$ Analogy with the Photo-Oxidation of $\mathrm{K}_{4}\left[\mathrm{Mo}^{\mathrm{IV}}(\mathrm{CN})_{8}\right] \cdot 2 \mathrm{H}_{2} \mathrm{O}$. J. Chem. Soc., Dalton Trans. 2000, 20, 3609-3614.

(56) MacRae, C. F.; Sovago, I.; Cottrell, S. J.; Galek, P. T. A.; McCabe, P.; Pidcock, E.; Platings, M.; Shields, G. P.; Stevens, J. S.; Towler, M.; Wood, P. A. Mercury 4.0: From Visualization to Analysis, Design and Prediction. J. Appl. Crystallogr. 2020, 53, 226-235.

(57) Nowicka, B.; Bałanda, M.; Gawel, B.; Ćwiak, G.; Budziak, A.; Łasocha, W.; Sieklucka, B. Microporous $\left\{[\mathrm{Ni}(\text { cyclam })]_{3}\left[\mathrm{~W}(\mathrm{CN})_{8}\right]_{2}\right\}_{n}$ Affording Reversible Structural and Magnetic Conversions. Dalton Trans. 2011, 40, 3067-3073.

(58) Nowicka, B.; Reczyński, M.; Rams, M.; Nitek, W.; Kozieł, M.; Sieklucka, B. Larger Pores and Higher $\mathrm{T}_{\mathrm{c}}:\left\{[\mathrm{Ni}(\text { cyclam })]_{3}[\mathrm{~W}-\right.$ $\left.(\mathrm{CN})_{8}\right]_{2} \cdot$ solv $\}_{\mathrm{n}}$ - a New Member of the Largest Family of PseudoPolymorphic Isomers among Octacyanometallate-Based Assemblies. CrystEngComm 2015, 17, 3526-3532.

(59) Pacanowska, A.; Reczyński, M.; Nowicka, B. Modification of Structure and Magnetic Properties in Coordination Assemblies Based on $[\mathrm{Cu}(\text { cyclam })]^{2+}$ and $\left[\mathrm{W}(\mathrm{CN})_{8}\right]^{3-}$. Crystals 2019, 9, 45.

(60) Larionova, J.; Clérac, R.; Donnadieu, B.; Willemin, S.; Guérin, C. Synthesis and Structure of a Two-Dimensional Cyano-Bridged Coordination Polymer $[\mathrm{Cu}(\text { cyclam })]_{2}\left[\mathrm{Mo}(\mathrm{CN})_{8}\right] \cdot 10.5 \mathrm{H}_{2} \mathrm{O}$ (cyclam = 1,4,8,11-Tetraazacyclodecane). Cryst. Growth Des. 2003, 3, 267272.

(61) You, Y. S.; Kim, D.; Do, Y.; Oh, S. J.; Hong, C. S. OneDimensional Octacyanomolybdate-Based $\mathrm{Cu}(\mathrm{II})-\mathrm{Mo}(\mathrm{V})$ Bimetallic 
Assembly with a Novel Rope-Ladder Chain Structure. Inorg. Chem. 2004, 43, 6899-6901.

(62) Lim, J. H.; You, Y. S.; Yoo, H. S.; Yoon, J. H.; Kim, J. Il; Koh, E. K.; Hong, C. S. Bimetallic $\mathrm{M}_{2}^{\mathrm{V}} \mathrm{Cu}_{3}{ }_{3}(\mathrm{M}=\mathrm{Mo}, \mathrm{W})$ Coordination Complexes Based on Octacyanometalates: Structures and Magnetic Variations Tuned by Chelated Tetradentate Macrocyclic Ligands. Inorg. Chem. 2007, 46, 10578-10586.

(63) Tokoro, H.; Nakagawa, K.; Nakabayashi, K.; Kashiwagi, T.; Hashimoto, K.; Ohkoshi, S. Photoreversible Switching of Magnetic Coupling in a Two-Dimensional Copper Octacyanomolybdate. Chem. Lett. 2009, 38, 338-339.

(64) Stoll, S.; Schweiger, A. Easy Spin, a Comprehensive Software Package for Spectral Simulation and Analysis in EPR. J. Magn. Reson. 2006, 178, 42-55.

(65) Chang, C. C.; Pfennig, B.; Bocarsly, A. B. Photoinduced Multielectron Charge Transfer Processes in Group 8 - Platinum Cyanobridged Supramolecular Complexes. Coord. Chem. Rev. 2000, $208,33-45$.

(66) Bridonneau, N.; Quatremare, P.; von Bardeleben, H. J.; Cantin, J. L.; Pillet, S.; Bendeif, E. E.; Marvaud, V. Direct Evidence of a Photoinduced Electron Transfer in Diluted "Molybdenum-Copper" Molecular Compounds. Eur. J. Inorg. Chem. 2018, 2018, 370-377.

(67) Long, J.; Chamoreau, L. M.; Marvaud, V. Supramolecular Heterotrimetallic Assembly Based on Octacyanomolybdate, Manganese, and Copper. Eur. J. Inorg. Chem. 2011, 2011 (29), 45454549.

(68) Long, J.; Chamoreau, L. M.; Mathonière, C.; Marvaud, V. Photoswitchable Heterotrimetallic Chain Based on Octacyanomolybdate, Copper, and Nickel: Synthesis, Characterization, and Photomagnetic Properties. Inorg. Chem. 2009, 48, 22-24.

(69) Visinescu, D.; Madalan, A. M.; Andruh, M.; Duhayon, C.; Sutter, J. P.; Ungur, L.; Van Den Heuvel, W.; Chibotaru, L. F. First Heterotrimetallic $\{3 \mathrm{~d}-4 \mathrm{~d}-4 \mathrm{f}\}$ Single Chain Magnet, Constructed from Anisotropic High-Spin Heterometallic Nodes and Paramagnetic Spacers. Chem. - Eur. J. 2009, 15, 11808-11814.

(70) Visinescu, D.; Jeon, I. R.; Madalan, A. M.; Alexandru, M. G.; Jurca, B.; Mathonière, C.; Clérac, R.; Andruh, M. Self-Assembly of $\left[\mathrm{Cu}^{\mathrm{II}} \mathrm{Tb}^{\mathrm{III}}\right]^{3+}$ and $\left[\mathrm{W}(\mathrm{CN})_{8}\right]^{3-}$ Tectons: A Case Study of a Mixture Containing Two Complexes Showing Slow-Relaxation of the Magnetization. Dalton Trans. 2012, 41, 13578-13581.

(71) Alexandru, M. G.; Visinescu, D.; Shova, S.; Andruh, M.; Lloret, F.; Julve, M. Synthesis, Crystal Structures, and Magnetic Properties of Two Novel Cyanido-Bridged Heterotrimetallic $\left\{\mathrm{Cu}^{\mathrm{II}} \mathrm{Mn}^{\mathrm{II}} \mathrm{Cr}^{\mathrm{II}}\right\}$ Complexes. Inorg. Chem. 2017, 56, 2258-2269.

(72) Alexandru, M. G.; Visinescu, D.; Shova, S.; Andruh, M.; Lloret, F.; Cano, J.; Julve, M. Three Different Types of Bridging Ligands in a $3 \mathrm{~d}-3 \mathrm{~d}^{\prime}-3 \mathrm{~d}^{\prime \prime}$ Heterotrimetallic Chain. Dalton Trans. 2018, 47, 10101013.

(73) Adams, C. J.; Haddow, M. F.; Hughes, R. J. I.; Kurawa, M. A.; Orpen, A. G. Coordination Chemistry of Platinum and Palladium in the Solid-State: Synthesis of Imidazole and Pyrazole Complexes. Dalton Trans. 2010, 39, 3714-3724. 